\title{
ANNOTATIONS
}

\section{Ophthalmic Miracles}

The eye has always lent itself to superstition, and blindness has ever been a favourite condition for miraculous healing. The case of Tobit in the Apocrypha is well known and forms the subject of an entertaining essay by Sir John Bland Sutton in one of his published volumes. Besides this, blindness and restoration of sight are of frequent occurrence in the Bible. Apart from spiritual blindness and that judicially inflicted, we get the example of the blindness inflicted on the men of Sodom, in Genesis, XIx, 11, and that inflicted on the Syrian army in 2 Kings vi, 18. But the best known examples are to be found in the New Testament, of Saul of Tarsus and of Elymas at Paphos in the Acts; while the four Evangelists together contain no fewer than seven miracles of the restoration of sight by Our Lord. That described by St. Mark in chapter viII, verses 22-26, contains that odd statement of the afflicted that he saw men as trees walking.

In early English history the Venerable Bede, in chapter 18 of his Ecclesiastical History, gives among other miracles the following worked by St. Germanus: "A certain man who had the quality of a tribune came forward with his wife, and presented his blind daughter, ten years of age, for the priests to cure. They ordered her to be set before their adversaries, who being convinced by guilt of conscience, joined their entreaties to those of the child's parents, and besought the priests that she might be cured. The priests, therefore, perceiving their adversaries to yield, made a short prayer, and then Germanus, full of the Holy Ghost, invoked the Trinity, and taking into his hands a casket with relics of the saints, which hung about his neck, applied it to the girl's eyes, which were immediately delivered from darkness and filled with the light of truth."

The Life of St. William of Norwich fairly bristles with miracles of this kind, sandwiched in between those of the cure of madness, epilepsy, deafness, fluxes, and dropsy. Apart from the records of miracles, this book is interesting as detailing the starting point, in this country at any rate, of the history of the myth of Jewish ritual murders. It was published by the Cambridge University Press in 1896, the editors being Canon Jessop of Norwich and Dr. M. R. James, now Provost of Eton.

The most remarkable ophthalmic miracle that we have met with in the course of a good deal of miscellaneous desultory reading is the one recorded by Giraldus Cambrensis in his 
Itinerary of Archbishop Baldwin through Wales in 1188. It concerns St. Kenelm, son of Kenulf, King of Mercia, and his sister, Quindreda.

"What miraculous power hath not in our days been displayed by the psalter of Quindreda, sister of St. Kenelm, by whose instigation he was killed? On the vigil of the Saint, when according to custom great multitudes of women resorted to the feast at Winchelcumbe (Winchcombe), the under butler of that convent had carnal knowledge of one of them within the precincts of the monastery. This same man on the following day had the audacity to carry the psalter in the procession of the relics of the saints; and on his return to the choir, after the solemnity, the psalter stuck to his hands. Astonished and greatly confounded, and at length calling to mind his crime on the preceding day, he made confession, and underwent penance; and being assisted by the prayers of the brotherhood, and having shown signs of sincere contrition, he was at length liberated from the miraculous bond. That book was held in great veneration, because when the body of St. Kenelm was carried forth, and the multitude cried out: 'He is the martyr of God; truly he is the martyr of God': Quindreda, conscious and guilty of the murder of her brother, answered, 'He is as truly the martyr of God, as it is true that my eyes be on that psalter'; for as she was reading the psalter, both her eyes were miraculously torn from her head, and fell on the hook, where the marks of the blood yet remain."

This is, we think, the most remarkable case on record of double evulsion.

\section{COUNCIL OF BRITISH OPHTHALMOLOGISTS}

\section{Medical Certificates of Blindness for Persons applying at Voluntary Hospitals}

In the Brit. Jl. of Ophthal., Sept., 1927, see p. 98, the Council of British Ophthalmologists published a statement drawn up by the Lady Almoner of Moorfields Eye Hospital on this subject.

The attention of the Council has since been drawn to certain points in that statement which have proved misleading, and, in response to further inquiries the Ministry of Health has supplied a declaration on the present position.

From the information contained in the last paragraph it appears that the voluntary agencies for the blind and the local authorities have power to remunerate an ophthalmic surgeon for providing a medical certificate of blindness. 